\section{Popivschyi V., Bezverkhyi A., Tatievskyi D.}

\title{
INVESTIGATION OF ROAD TRAIN DIVERGENT STABILITY LOSS WHEN MOVING ALONG A PROGRAM TRAJECTORY
}

Об’єктом дослідження є транспортні керовані багатоланкові колісні системи. У розвиток реалізованої можливості керованого руху сідельного автопоїда за програмною траєкторією в даному дослідженні розглянуто можливість побудови біфуркаційної множини за параметром швидкості. Значення швидкості обчислюється для кожного дискретного значення обчисленої реальної траєкторії. Траєкторія може бути задана в явному, неявному, параметричному вигляді або законом зміни радіуса кривизни. Дослідження ц,ього параметра є одним із найпроблемніших місць аналізу стійкості руху автопоїзда.

Зміни цього параметра при певних значеннях, званих біфуркаційними, призводять до змін в якісній структурі рішень системи диферениіальних рівнянь $i$, як наслідок, дивергентної втрати стійкості автопоїзда. Для дослідження цього явища застосований метод продовження за параметром і перший метод Ляпунова.

В ході дослідження отримана множина біфуркаційних значень швидкостей. Це пов'язано з тим, що запропонований підхід має ряд особливостей, зокрема, виконано ітерування за всіма параметрами управління програмної траєкторї, $і$ для кожного такого значення застосовано ітерування за швидкістю до досягнення ї̈ біфуркаиійного значення.

На кожній ітерачї виконується перевірка коренів характеристичного рівняння на наявність хоча $б$ одного кореня з позитивною дійсною частиною, що відповідає біфуркаційному значенню параметра швидкості руху автопоїда за Ляпуновим. Завдяки цьому забезпечується можливість отримання цієї множини виключно аналітичним методом за допомогою комп'ютерних обчислень, не вдаючись до використання графоаналітичних методів. У дослідженні згенеровані біфуркаційні множини швидкостей для різних програмних траєкторій.

Обчислення цих біфуркаційних множин може практично використовуватися як для обмеження швидкості руху автопоїза, так $і$ для попередження про ї перевищення. У порівнянні з аналогічними відомими методами ще забезпечує такі переваги, як значне прискорення побудови чієї множини $і$, як наслідок, ї використання в режимі реального часу.

Ключові слова: характеристичне рівняння, перший метод Ляпунова, метод продовження за параметром, біфуркаційна множина, дивергентна втрата стійкості.

\section{Introduction}

From the point of view of the safety of the movement of a semi-trailer truck, special attention should be paid to the analysis of the conditions under which an abrupt change in the orientation of the semi-trailer is possible (internal and external). This is the so-called fold bifurcation, which corresponds to the divergent loss of stability of the circular stationary mode with a variation of the longitudinal velocity. The set of parameters at which such abrupt transitions of stationary states occur is a critical set or a bifurcation set. Among them, for the system under consideration, it is possible to distinguish both control parameters (movement velocity, steering wheel angle of rotation) and characteristic parameters (linear dimensions of the system components, their masses, etc.).

This research addresses the task of building a bifurcation set of velocities for a synthesized [1] controlled motion along a given programmed trajectory containing a set of coordinates of the tractor and trailer, the angle of rotation of the steering wheels and the folding angle.

Obtaining set of these parameters is relevant because it allows to organize the management of the road train using feedback. Planned studies can provide additional control over the maximum allowable velocity of movement in order to avoid bifurcation effects, thereby contributing to increased traffic safety.

\section{The object of research and its technological audit}

The object of research is transport driven multilink wheel systems. A flat bicycle model of the movement of the semi-trailer truck [2] is considered. The articulated crew diagram is shown in Fig. 1, where:

$v$ - longitudinal component of the center of mass of the tractor;

$\theta$ - rotation angle of the controlled module;

$a, b$ - distance from the center of mass of the tractor to the centers of the front (steered) axis and the rear axle of the tractor;

$c$ - distance from the center of mass of the tractor to the point of coupling with the second link;

$d_{1}$ - distance from the center of mass of the second link to the hitch point with the tractor;

$Y_{i}$ - removal forces on the axes, drag coefficients on the axes $\left(k_{1} ; k_{2} ; k_{3}\right)$; 
$m$ - tractor mass;

$u$ - transverse projection of the velocity vector of the center of mass of the tractor;

$\omega$ - angular velocity of the tractor relative to the vertical axis;

$m_{2}-$ mass of the second link;

$v_{1}, u_{1}-$ longitudinal and transverse projections of the velocity vector of the center of mass of the semi-trailer;

$\varphi$ - folding angle (the angle between the longitudinal axis of the tractor and the semi-trailer).

The subject of research is mathematical models of the dynamics of controlled motion of multi-link wheeled transport systems with the possibility of divergent loss of stability.

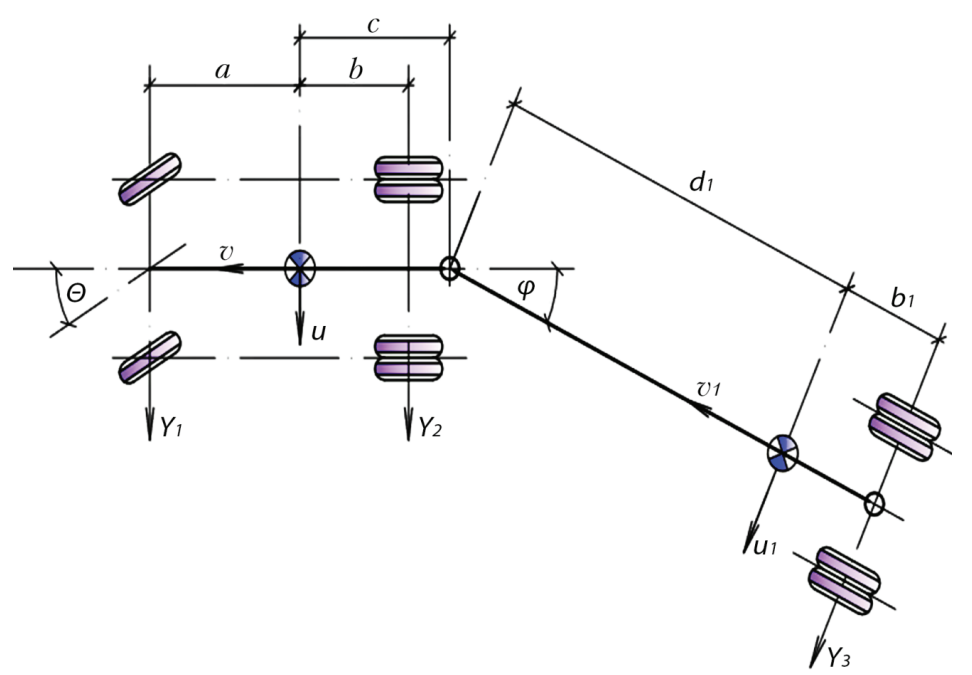

Fig. 1. Constructive scheme of the model of two-link road train

One of the most problematic places in the movement of road trains is the possibility of divergent loss of stability when the maximum permissible velocities are exceeded. The construction of such a set of velocities when moving along a program trajectory is implemented in this research with the aim of improving traffic safety.

\section{The aim and objectives of research}

The aim of research is realization of the possibility of analytically constructing a bifurcation set of velocities when moving along a controlled program trajectory using the first Lyapunov method for calculating bifurcation values together with the method of continuation by parameter.

To achieve this aim, the following objectives are:

1. Numerical integration of a system of differential equations with a synthesized control law.

2. Construction of a bifurcation set of velocities for a discrete set of control values using the first Lyapunov method and the method of continuation over a parameter by iterating over velocity.

3. Visualization of the set of critical control parameters (bifurcation sets) for various program trajectories and modeling (visualization) of the system motion.

\section{Research of existing solutions of the problem}

Among the studies of the problem of loss of divergent stability by road train, let's note the work on real bifurcations of two-link systems with rolling [3]. The issues of qualitative analysis of nonlinear models of wheeled vehicles with the involvement of elements of the theory of bifurcations are studied in [4]. In [5], an approach is implemented that allows one to obtain a more complete representation of the bifurcation set of the model of a semi-trailer truck in an analytical form. It should be noted also the work on the determination and analysis of the stability of circular stationary driving modes of the model of a semi-trailer truck [6,7]. The analysis of the movement stability of a semi-trailer truck model from the point of view of determining its maneuverability is also considered in $[8,9]$. Mathematical modeling of a semitrailer truck with a controlled semi-trailer and analysis of its stability is performed in [10].

The studies mentioned above, as a rule, are aimed at the further development of the graphoanalytical approach to analyzing the set of stationary modes of the non-linear model of a twolink trailer using the ideas of bifurcation analysis. However, the problems of divergent loss of stability of a train when moving along a program trajectory are not considered in these studies and are proposed for the first time in this paper.

Some studies [11,12] are purely experimental in nature and are useful in creating a specialized robotic installation tractor-semitrailer, which represents a certain rarity. In connection with the proposed further experiments with this installation and its improvement, attention is drawn to specialized studies on unstable driving conditions at high velocities [13]. And also on the features of the synthesis of safe control for AHV (Articulated Heavy Vehicle) systems [14].

Of particular interest are studies of the stability of the yaw of a tractor-semitrailer system in constant driving conditions, analyzed using the theory of bifurcations [15].

Note that recently the theory of bifurcations and the corresponding analytical methods have been successfully applied to the study and control of some engineering systems, such as associated satellite systems, jet engine compressors, longitudinal flight dynamics and system power [16, 17]. The technologies of bifurcation analysis described in these studies are also of considerable interest.

In addition to the divergence loss of stability considered in this research (fold bifurcation), the Hopf bifurcation (limit cycle) is also studied in papers [18, 19], which also occurs during the road train movement.

An analysis of these publications leads to the conclusion in favor of the proposed research methods that allow for effective computer implementation.

\section{Methods of research}

In this research, an exclusively analytical approach is used using the first Lyapunov method [20] and the parameter continuation method [21, 22], while practically identical results are obtained for identical models.

To solve these problems, let's the methods of the dynamics of a system of connected bodies, the mathematical apparatus of the theory of stability, the theory of bifurcations and controls, symbolic transformations and numerical methods, and heuristic search algorithms. 


\section{Research results}

The model of a two-link road train described above takes into account the effects of linear lateral withdrawal forces $Y_{i}$, which, according to Rocard's axiomatics [23], are determined by the relations:

$$
Y_{i}=k_{i} \cdot \delta_{i}(i=1,2,3),
$$

where $\delta_{i}(i=1,2,3)$ - angles of withdrawal (reduced) on the axes.

With steady motion on a circle of a given radius, the following relationship takes place:

$$
\omega=\frac{v}{R},
$$

where $v$ - the longitudinal component of the velocity of the center of mass of the tractor; $R$ - the radius of the trajectory of the point on the longitudinal axis of the tractor, the velocity of which is directed along the longitudinal axis of the tractor.

The condition of divergent loss of stability (according to Lyapunov) will be the presence of at least one root with a positive real part when solving the characteristic equation of system (1).

Results are obtained for the following numerical values of the parameters:

- $g=9,81 \mathrm{~m} / \mathrm{s}^{2} ; a=4,217 \mathrm{~m} ; b=3,376 \mathrm{~m} ; b_{1}=2,93 \mathrm{~m} ;$

$d_{1}=8,075 \mathrm{~m} ; c=3,376 \mathrm{~m}$;

- $m=6417 \mathrm{~kg} ; m_{2}=41846 \mathrm{~kg}$;

$k_{1}=100000 \mathrm{~N} ; k_{2}=300000 \mathrm{~N} ; k_{3}=300000 \mathrm{~N}$;

$-\kappa_{1}=0,8 ; \kappa_{2}=0,8 ; \kappa_{3}=0,8$.

The longitudinal forces in the contact patch of the wheels with the supporting surface are not taken into account. The lateral slip forces are approximated as an arctangent.

To solve the problem, the Maple system is used and a specially developed $\mathrm{C} \#$ application using the OpenMapleAPI technology, which allows automating (interactively changing the model parameters) a script implemented in the internal language of the Maple system.

In the Maple system, let's write the expressions for the dynamic equations:

$\mathrm{e} 1:=-\mathrm{m}^{*}\left(\mathrm{U}+\right.$ omega $\left.^{*} \mathrm{v}\right)+\mathrm{Y} 1+\cos (\mathrm{phi}) * \mathrm{Y} 3-2 * \mathrm{~m} 2 * \sin (\mathrm{phi}) *$ omega* ${ }^{*}{ }^{*} \mathrm{Phi}+\mathrm{m} 2 * \sin (\mathrm{phi}) * \mathrm{~d} 1{ }^{*} \mathrm{Phi}^{\wedge} 2+\mathrm{m} 2 * \cos (\mathrm{phi}) * \mathrm{~d} 1 *$ Omega-m $2^{*} \cos ($ phi $) * d 1 * \mathrm{PP}+\mathrm{m} 2 * \sin (\mathrm{phi}) * \mathrm{~d} 1{ }^{*}$ omega ${ }^{\wedge} 2+$ $\mathrm{Y} 2-\mathrm{m} 2 * \mathrm{U}+\mathrm{m} 2 * \mathrm{c}^{*}$ Omega-m $2 *$ omega* ${ }^{*}$;

e2: $=c^{*} \mathrm{~m} 2 *$ omega*v-b*Y2-J*Omega +

$\mathrm{c}^{*} \mathrm{~m} 2 * \cos (\mathrm{phi}) * \mathrm{~d} 1{ }^{*} \mathrm{PP}-\mathrm{c}^{*} \mathrm{~m} 2 * \sin (\mathrm{phi}) * \mathrm{~d} 1{ }^{*} \mathrm{Phi}{ }^{\wedge} 2-\mathrm{c}^{*} \mathrm{~m} 2 *$ $\cos (\text { phi })^{*} \mathrm{~d} 1 *$ Omega $+\mathrm{a}^{*} \mathrm{Y} 1+\mathrm{c}^{*} \mathrm{~m} 2 * \mathrm{U}-\mathrm{m} 2{ }^{*} \mathrm{c}^{\wedge} 2^{*}$ Omega-c* $\cos ($ phi $) * \mathrm{Y}^{*}-\mathrm{c}^{*} \mathrm{~m} 2 * \sin ($ phi $) * \mathrm{~d} 1{ }^{*}$ omega $^{\wedge} 2+2 * \mathrm{c}^{*} \mathrm{~m} 2 *$ $\sin ($ phi $) *$ omega*d1*Phi;

e3:=-J2*(Omega-PP)-L1*Y3+d1* $\cos ($ phi $) * m 2 * U+$ $\mathrm{d} 1 * \cos (\mathrm{phi}) * \mathrm{~m} 2 *$ omega*v-d1* $\sin (\mathrm{phi}) * \mathrm{~m} 2 *$ omega* $\mathrm{u}-\mathrm{d} 1 \wedge 2 * \mathrm{~m} 2 *$ Omega $+\mathrm{d} 1 \wedge 2^{*} \mathrm{~m} 2 * \mathrm{PP}-\mathrm{c}^{*} \mathrm{~m} 2 * \cos (\mathrm{phi}) *$ $\mathrm{d} 1{ }^{*}$ Omega $+\mathrm{c}^{*} \mathrm{~m} 2{ }^{*} \sin (\mathrm{phi}) * \mathrm{~d} 1{ }^{*}$ omega ${ }^{\wedge} 2$.

In these expressions (the system of differential equations of motion):

- $U-$ the derivative of the lateral component of the center of mass;
- Omega - the derivative of the angular velocity (omega) relative to the vertical axis;

- Phi - the rate of change of the angle of rotation (phi) of the rear link;

- PP - the angular acceleration of the rear link.

Calculating the Jacobian of the system Joo, let's obtain the characteristic equation:

chp: = linalg[charpoly](Joo,lambda);

and its roots:

eigv: = evalf(solve(chp,lambda)).

The application determines the moment of the appearance of the root with a non-negative real part by varying the velocity value.

Fig. 2 is general view of the application with the prebifurcation state of the road train (all the roots of the characteristic equation with a negative real part).

Divergent instability is realized at a velocity of $v=$ $=11.5 \mathrm{~m} / \mathrm{s}-$ obtained in [5], based on the numericalanalytical method of continuation with two parameters.

Using the developed application, it is possible to set an arbitrarily small calculation error; a more accurate value of $11.5009 \mathrm{~m} / \mathrm{s}$ is obtained.

The bifurcation velocity value is obtained by the continuation method with respect to the parameter with a step of 0.0001 (this is the required accuracy), in Fig. 3 - loss of divergent stability - the appearance of roots with a positive real part.

To build a set of bifurcation values, iteration is performed over all control parameters of the program trajectory, and for each such value, the velocity is iterated until its bifurcation value is reached. To velocity up such a process, initial (threshold) values of velocities are empirically determined. At each iteration, the roots of the characteristic equation are checked for the presence of at least one root with a positive real part, which will correspond to the bifurcation value of the parameter of the velocity of movement of the train.

Thus, Fig. 4 shows the generated bifurcation sets of velocities for various program trajectories. In this case, the bifurcation set of velocities in $\mathrm{m} / \mathrm{s}$ is displayed in red, the control in degrees is green.

In this case, the parabola is set:

- explicit function $y(x)=5^{*} x^{2} / 216$;

- circle $y(x)=-\left(R^{2}-x^{2}\right)^{1 / 2}+R, R=30 \mathrm{~m}$ - rotate $90^{\circ}$;

- sinusoid $y(x)=3^{*} \sin \left(0.1^{*} x\right)$.

Clothoid is set parametrically in the Maple scenario as (parametrized by Fresnel integrals):

$$
\begin{aligned}
& \mathrm{X}(\mathrm{t}):=200^{*}\left(\operatorname{int}\left(\cos \left((1 / 2)^{*} \mathrm{Pi}^{*} \mathrm{u}^{\wedge} 2\right), \mathrm{u}=0 . . \mathrm{t}\right)\right) \\
& \mathrm{Y}(\mathrm{t}):=200^{*}\left(\operatorname{int}\left(\sin \left((1 / 2)^{*} \mathrm{Pi}^{*} \mathrm{u}^{\wedge} 2\right), \mathrm{u}=0 . . \mathrm{t}\right)\right)
\end{aligned}
$$

The construction of a bifurcation set makes it possible to determine the maximum allowable velocity of movement along a program trajectory without divergent loss of stability; this is the minimum velocity value in the bifurcation set. At subcritical velocity, the motion is stable, the program and real trajectories (red and blue) coincide (Fig. 5).

When it is exceeded, bifurcation phenomena are observed (Fig. 6, the real trajectory is shown in blue). 


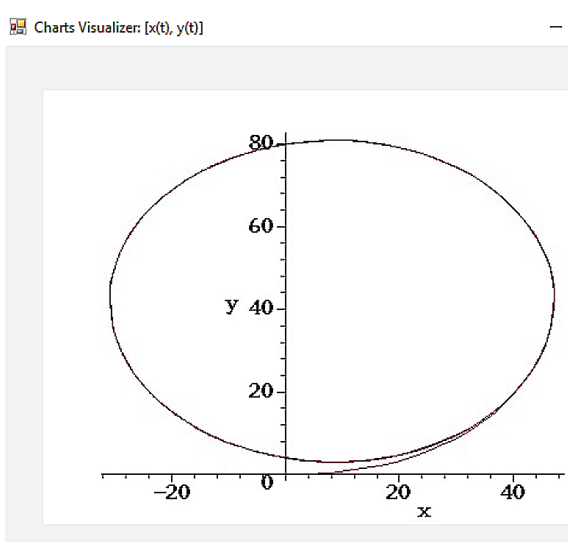

踢 Charts Visualizer: $[$ seq([R]],Mn[j]],j=1.4)

$\square \quad x$

Fig. 2. Pre-bifurcation state of the system

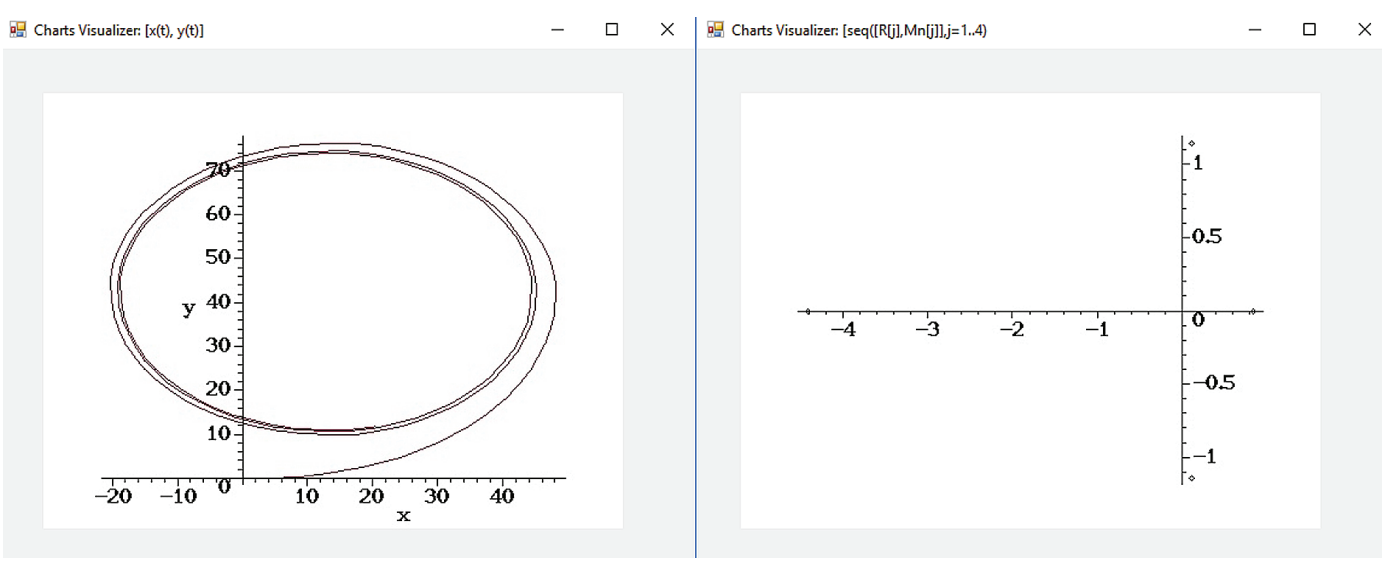

Fig. 3. Calculation of the bifurcation velocity value
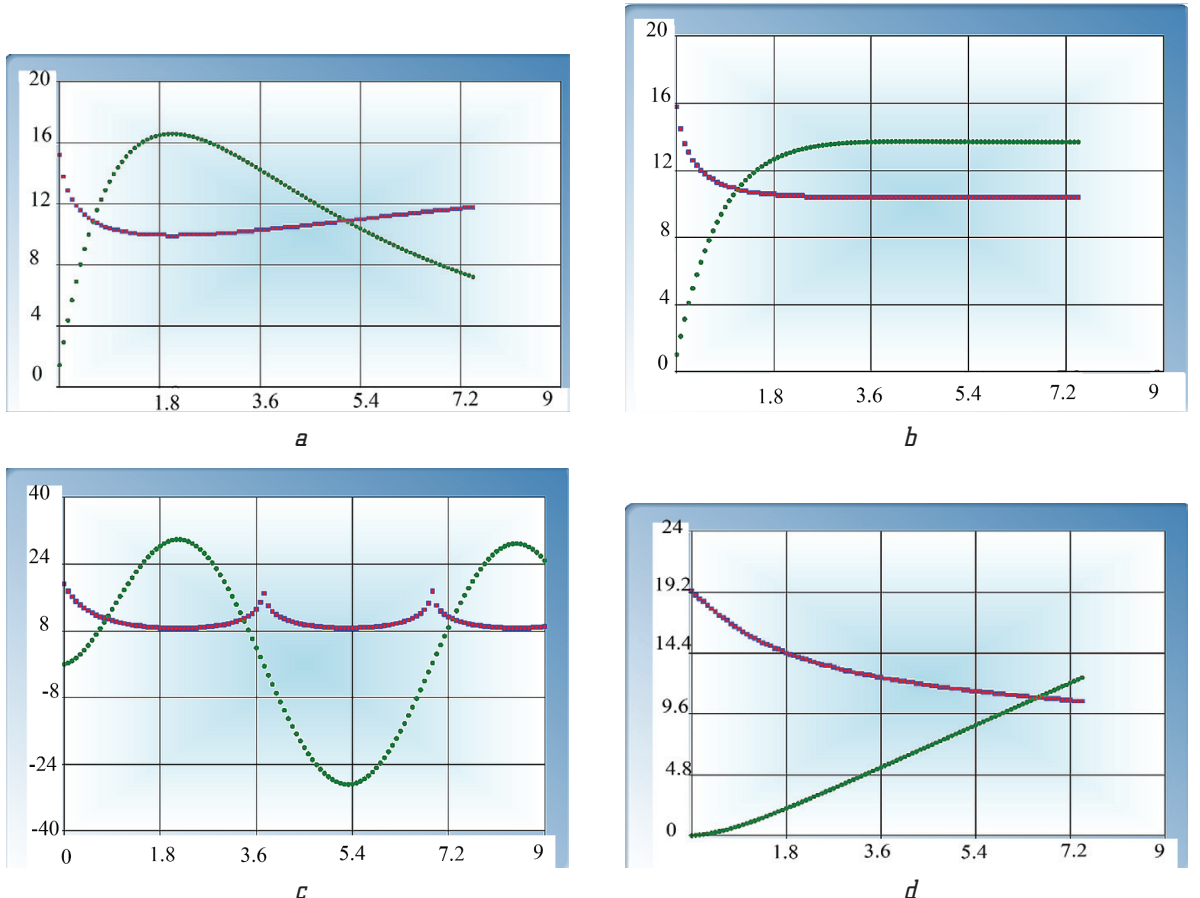

Fig. 4. Generated bifurcation sets of velocities for various program trajectories: $a$ - parabola; $b$ - circle; $c$ - sinusoid; $d-$ clothoid

For the initial model, the divergent loss of stability for this maneuver is realized at a velocity of $11.3 \mathrm{~m} / \mathrm{s}$ - its minimum value in the bifurcation set.
Fig. 7 illustrates the divergent loss of stability of a road train when moving through a clothoid at various velocities. 


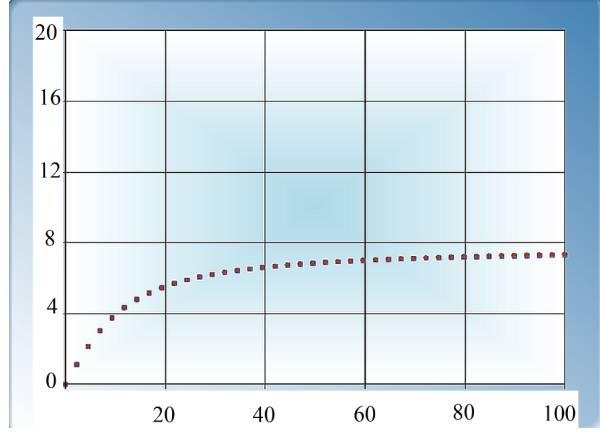

Fig. 5. «Rearrangement» maneuver with subcritical velocity $(v=11.1 \mathrm{~m} / \mathrm{s})$

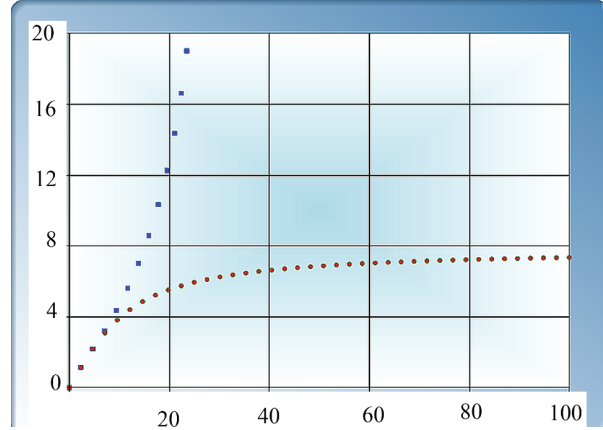

Fig. 6. Divergent loss of stability when «rearrangement maneuver $(v=11.4 \mathrm{~m} / \mathrm{s})$

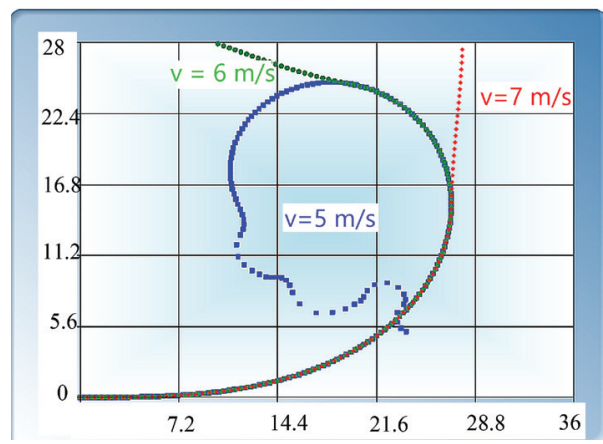

Fig. 7. Divergent loss of stability when moving along the clothoid

The lower the velocity, the larger part of the clothoid can be passed without divergent buckling.

In addition to obtaining bifurcation velocities, the application allows to vary the control parameter (at a constant velocity or simultaneously). It is also possible to vary the characteristic parameters, which, obviously, is important at the design stage of two-link systems, constructing appropriate bifurcation sets for them.

\section{SWOT analysis of research results}

Strengths. The strengths of the proposed method include the fact that the basis of the mathematical model of the controlled motion of semi-trailer truck is based on the classical principles of the mechanics of a system of solids (taking into account the presence of nonholonomic bonds). The task of synthesizing software-controlled motion is solved on the basis of strictly grounded approaches of the theory of automatic control and control of dynamic systems. The correctness of the obtained results is verified on the basis of an independent numerical simulation of the system.
The implementation of the construction of a bifurcation set of velocities by an exclusively analytical method allows to significantly velocity up the process of such construction and makes it possible to apply this approach in real time, informing the driver of the road train about the inadmissibility of velocity.

Weaknesses. The weak sides should be attributed to the insufficient accumulation of experimental empirical material, although the experiments carried out with a specially developed robotic installation (tractor-semitrailer) show good agreement with the theory. The developed installation at the moment has a number of design flaws (limited control, wheel slip), which requires its technical improvement.

Opportunities. Opportunities for further research are the technical improvement of the experimental setup developed and the further study of driver's maneuvers with the construction of bifurcation sets for them.

Threats. When introducing the results of this research, it is necessary to develop a technical device with functions that help improve the safety and efficiency of driving a vehicle by obtaining values from a bifurcation set of velocities in real time. For each alert, the device can play a beep or display information on the display.

\section{Conclusions}

1. A numerical integration of a system of differential equations with a synthesized control law in the system of symbolic Maple calculations is performed. Such integration is performed on each discrete controlled trajectory in a specially designed application. The results of numerical integration are visualized in the form of data of phase portraits and solutions of the characteristic equation of the system.

2. The bifurcation velocity set is constructed for a discrete set of control values using the first Lyapunov method and the parameter continuation method by iterating over velocity. The method of continuation by parameter is also applied to the control and the characteristic parameters of the model, which makes it possible to obtain bifurcation sets depending on changes in these parameters. These results can be used at the design stage of multilink systems, determining their optimal linear dimensions.

3. Visualization of a set of critical parameters of velocity and control for various software trajectories (typical driver maneuvers) and modeling of the system movement in the Unity 3D environment and using the developed robotic installation are implemented. This visualization allows to explore the movement of a road train at the time of bifurcation and develop recommendations for the management of a road train to get out of this situation. In the absence of slippage and surface irregularities, the experimental results of the installation correspond to the theoretical ones.

\section{References}

1. Verbitskiy V. G., Polyakova N. P., Tatievskiy D. N. Issledovanie vozmozhnosti realizatsii upravlyaemogo dvizheniya avtopoezda vdol' programmnoy krivoy // Vcheni zapiski Tavriys'kogo natsional'nogo universitetu imeni V. I. Vernads'kogo. Seriya: Tekhnichni nauki. 2018. Vol. 29, Issue 6 (68). P. 2-4.

2. Verbitskiy V. G., Lobas L. G. Veshhestvennye bifurkatsii dvukhzvennykh sistem s kacheniem // Prikladnaya matematika i mekhanika. 1996. Issue 3. P. 418-425. 
3. Verbitskiy V. G., Lobas L. G. Bifurkatsii statsionarnykh sostoyaniy svyazki absolyutno tverdykh i katyashhikhsya uprugikh tel // Izvestiya AN SSSR. Mekhanika tverdogo tela. 1991. Issue 3. P. 30-37.

4. Lobas L. G., Verbitskiy V. G. Kachestvennye i analiticheskie metody v dinamike kolesnykh mashin. Kyiv: Naukova dumka 1990. 216 p.

5. Verbitsky V., Bezverkhyi A., Tatievskyi D. Handling Analysis and Defining Conditions of Dangerous-Sfe Divergent Stability Loss of a Two-Link Road Train Nonlinear Model // Mathematical Modelling and Applications. 2018. Vol. 3, Issue 2. P. 31-38. doi: http://www.sciencepublishinggroup.com/journal/ paperinfo? journalid $=247 \&$ doi $=10.11648 / \mathrm{j} \cdot \mathrm{mcs} .20180301 .13$

6. Verbitskiy V. G., Zagorodnov M. I. Opredelenie i analiz ustoychivosti krugovykh statsionarnykh rezhimov dvizheniya modeli sedel'nogo avtopoezda // Visnik Donets'kogo in-tu avtomob. Transportu. 2007. Issue 1. P. 10-19.

7. Verbitskiy V. G., Lobas L. G. Mnogoobraziya statsionarnykh sostoyaniy dvukhzvennogo avtopoezda i ikh ustoychivost' // Prikladnaya mekhanika. 1990. Issue 12. P. 97-104.

8. Moysya D. L., Bumaga A. D. Opredelenie manevrennosti i analiz ustoychivosti dvizheniya modeli sedel'nogo avtopoezda // Visnik Donets'kogo in-tu avtomob. transportu. 2007. Issue 3. P. $10-19$.

9. Moysya D. L. Analiz statsionarnykh sostoyaniy i ikh ustoychivosti trekhzvennogo avtopoezda s bezopornym promezhutochnym zvenom avtopoezda // Vistnik Natsional'nogo transportnogo universitetu. 2008. Issue 17. P. 8-13.

10. Verbytskyi V. H., Moisia D. L. Matematychna model sidelnoho avtopoizda z kerovanym napivprychepom // Mizhvuzivskyi zbirnyk «Naukovi notatky». 2010. Issue 28. P. 98-103.

11. Kaneko T., Kageyama I. A study on the braking stability of articulated heavy vehicles // JSAE Review. 2003. Vol. 24, Issue 2. P. 157-164. doi: http://doi.org/10.1016/s0389-4304(03)00007-9

12. Analiz rezultativ doslidzhennia kursovoi stiikosti rukhu eksperymentalnoho avtopoizda v stalomu rusi / Bondarenko A. Ye. et. al. // Visnyk Donetskoi akademii avtomobilnoho transportu. 2010. Issue 2. P. 53-61.

13. Ei-Gindy M., Mrad N., Tong X. Sensitivity of rearward amplication control of a truck/full trailer to tyre cornering stiffness variations // Proceedings of the Institution of Mechanical Engineers, Part D: Journal of Automobile Engineering. 2001. Vol. 215, Issue 5. P. 579-588. doi: http://doi.org/10.1243/0954407011528176

14. Abdulwahab A. Investigations on the Roll Stability of a Semitrailer Vehicle Subjected to Gusty Crosswind Aerodynamic Forces: Doctoral thesis. University of Huddersfield, 2018. 239 p.
15. Analysis of bifurcation and stability for a tractor semi-trailer in planar motion / Ding N. et. al. // Vehicle System Dynamics. 2014. Vol. 52, Issue 12. P. 1729-1751. doi: http://doi.org/10.1080/ 00423114.2014 .960431

16. di Bernardo M. Bifurcation analysis for control systems applications / ed. by Chen G., Hill D. J., Yu X. // Bifurcation control theory and application. Heidelberg: Springer-Verlag, 2003. P. 249-264.

17. Catino B., Santini S., di Bernardo M. MCS adaptive control of vehicle dynamics: an application of bifurcationtechniques to control system design // 42nd IEEE conference on decision and control. Maui: IEEE, 2003. Vol. 3. P. 2252-2257. doi: http://doi.org/10.1109/cdc.2003.1272953

18. Troger H., Zeman, K. Application of Bifurcation Theory to Tractor-Semitrailer Dynamics // Vehicle System Dynamics. 1981. Vol. 10, Issue 2-3. P. 156-161. doi: http://doi.org/10.1080/ 00423118108968660

19. Troger H., Zeman K. A Nonlinear Analysis of the Generic Types of Loss of Stability of the Steady State Motion of a TractorSemitrailer* // Vehicle System Dynamics. 1984. Vol. 13, Issue 4. P. 161-172. doi: http://doi.org/10.1080/00423118408968773

20. Lyapunov A. M. Obshhaya zadacha obustoychivosti dvizheniya. Cherepovets: Merkuriy-PRESS. 2000. 386 p.

21. Shinohara Y. A geometric method for the numerical solution of nonlinear equations and its application to nonlinear oscillations // Publications of the Research Institute for Mathematical Sciences. 1972. Vol. 8, Issue 1. P. 13-42. doi: http://doi.org/10.2977/ prims/1195193225

22. Metody analiza nelineynykh dinamicheskikh modeley / Kholodniok M. et. al. Moscow: Mir, 1991. 368 p.

23. Rokar I. Neustoychivost'v mekhanike / ed. by Obmorshev A. N Moscow: Izd-vo inostr. lit., 1959. 287 p.

Popivshchyi Vasyl, PhD, Associate Professor, Department of Computerized System Software, Zaporizhzhya State Engineering Academy, Ukraine, e-mail: pvi@zsea.edu.ua, ORCID: http://orcid.org/ 0000-0002-2673-987X

Bezverkhyi Anatoliy, PhD, Associate Professor, Department of Computerized System Software, Zaporizhzhya State Engineering Academy, Ukraine,e-mail: anatoliy.bezverkhyi@hotmail.com, ORCID: http://orcid.org/0000-0002-0819-3690

Tatievskyi Dmitry, Postgraduate Student, Department of Computerized System Software, Zaporizhzhya State Engineering Academy, Ukraine, e-mail: dtdissert@gmail.com, ORCID: http://orcid.org/ 0000-0002-7841-9560 